\title{
Research on numerical calculation method of crack width of steel lined reinforced concrete penstock laid on downstream surface of dam
}

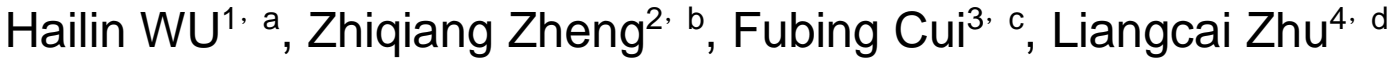 \\ College of Hydraulic \& Environmental Engineering, Three Gorges University, Yichang 443002, \\ China \\ awuhailinwhl@163.com,b779804453@qq.com
}

\begin{abstract}
Keywords: Steel lined penstock laid on downstream face of dam, Finite element, Crack width
Abstract: In this paper the finite element method for calculating the crack width of reinforced concrete structures is deduced. Based on the model test of the back dam model of the Three Gorges Dam, the nonlinear finite element analysis of the pressure pipeline model is carried out and the numerical results are compared with the model test results. The results show that the crack propagation load, the crack propagation process, the steel stress and the pipeline displacement are in good agreement with the model test results. Under the design of internal water pressure the maximum crack width calculated by the crack width finite element method is $0.477 \mathrm{~mm}$.It's significantly larger than the maximum crack width obtained by the standard crack width calculation formula $0.285 \mathrm{~mm}$, which is closer to the actual measured crack width of many hydropower station pressure pipelines.
\end{abstract}

\section{Introduction}

Penstock laid on downstream face of dam is being widely used in large-scale hydropower stations. The pipeline structure diameter with the expansion of the scale and continue to expand. When the penstock laid on downstream face of dam work, due to the water pressure, temperature and other effects. The outsourcing of concrete has cracked. The size of the wall crack width, related to the durability of the pipeline. In the design it is necessary to have a certain accuracy estimate of the wall crack width at work to solve the crack control problem. Many experts and scholars at home and abroad have done some model tests, prototype observation and theoretical analysis for this kind of pipeline and put forward the formula of calculating the crack width specifically for the pressure pipeline structure. Such as Zeren Dong formula, Ran Tao formula Kangpin Wang formula and the former Soviet Union steel pipeline reinforced concrete structure design reference material crack width calculation method and so on[1]. In the engineering design phase most of the actual project of the crack width of the calculated value can be less than the allowable crack width limit of $0.3 \mathrm{~mm}$ design requirements. And the width of the crack observed in the actual engineering of the pressure pipeline of the hydropower station is often larger than the limit value. The measured crack width is even 2-7 times of the design limit.

The development of numerical analysis technology opens up a new way for the calculation of crack width for the finite element calculation of crack width under load. A lot of research work has been carried out both at home and abroad. Ngo and Scordelis[2] first applied the finite element method to the calculation of reinforced concrete structures; Yupu Song and Guopan Zhao[3], Shengxing $\mathrm{Wu}[4]$ and so on, the finite element method has been used to calculate the crack width of reinforced concrete beam-plate structure. In this paper the nonlinear finite element method is used to calculate and analyze the pressure pipelines of the Three Gorges Hydropower Station. Based on the existing calculation method of concrete crack width [3] the influence coefficient of concrete elongation on crack width is considered. Through the numerical analysis of the actual crack spacing within the scope of reinforcement strain value to calculate the crack width of concrete pipeline outsourcing. And the finite element calculation results of the crack width are compared with the model test and the calculated values. Discussing the applicability and effectiveness of finite element method to calculate the crack width. 


\section{Finite element method for crack width of reinforced concrete member}

In order to realize the crack width calculation in finite element, the method of crack width calculation is proposed by reference [3]. When the concrete cracks, the width of the crack in the center of the bar is used to indicate the elongation difference between the bar and concrete between adjacent cracks, as shown in figure 1.

$$
W=\int_{0}^{l_{c r}} \varepsilon_{S X} d x-\int_{0}^{l_{c r}} \varepsilon_{c X} d x=\sum_{0}^{n^{\prime}} \varepsilon_{s i} \Delta_{X i}-\sum_{0}^{n^{\prime}} \varepsilon_{c i} \Delta_{X i}
$$

Where, $\varepsilon_{s x}$ the strain value of the reinforcement unit in the direction perpendicular to the crack, $\varepsilon_{c x}$ is the strain value of the concrete unit perpendicular to the crack direction, $\Delta_{x i}$ is the length of the unit perpendicular to the crack direction and within the crack pitch, $n$ is the number of cells within the crack spacing.

In general meshing, the length of each cell in the crack spacing range is the same.

$$
n^{\prime}=1_{c r} / 1
$$

Where, n' may not be an integer, that is there are only a part of the individual unit length in the crack spacing; $1_{c r}$ is crack spacing, 1 is the length of a single reinforcing bar unit.

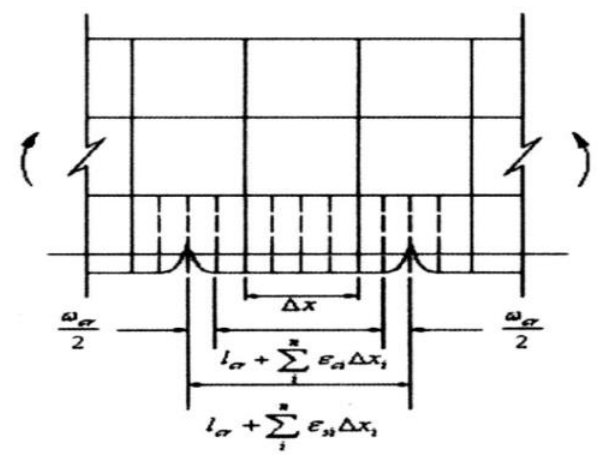

Fig.1 Relationship between steel strain and crack width

For the crack spacing can be considered as follows: for beam-column members with normal cross-section failure control, the crack spacing can be estimated according to the proposed formula for the crack spacing in the relevant design specifications; for complex force components, The solution of the crack spacing can also be obtained from the result of the fine numerical simulation, and the crack spacing is obtained by the fine finite element analysis of the local members, and then applied to the analysis method of the macroscopic size structure [5]. The formula (1) can be expressed as follows:

$$
W=\sum_{i=1}^{n} \varepsilon_{s i} \Delta x_{i}+\varepsilon_{s j} \Delta x_{j}-\sum_{i=1}^{n} \varepsilon_{c i} \Delta x_{i}-\varepsilon_{c j} \Delta x_{j}
$$

In the reinforced concrete structure, the concrete strain is very small compared with the reinforced, which can be neglected, and the formula of calculating the crack width is as follows:

$$
W=\sum_{i=1}^{n} \varepsilon_{s i} \Delta x_{i}+\varepsilon_{s j} \Delta x_{j}
$$

In the finite element model, the effect of concrete on the deformation of steel bars can't be neglected due to the large interaction between steel and concrete. Therefore, it is not reasonable to use the steel element strain to calculate the crack width directly, the average crack width is theoretically equal to the difference between the average tensile elongation of the reinforcement and the concrete in the average crack spacing range. The calculation formula is shown below:

$$
W=\Delta \varepsilon_{m} I_{c r}=\left(\varepsilon_{s m}-\varepsilon_{c m}\right) I_{c r}=\varepsilon_{s m}\left(1-\frac{\varepsilon_{c m}}{\varepsilon_{s m}}\right) I_{c r}
$$

Where, $\varepsilon_{s m}$ is the average strain of the rebar in the range of the crack spacing; $\varepsilon_{c m}$ is the average 
strain of concrete in the range of crack spacing; $\Delta \varepsilon_{m}$ is the average strain difference between the reinforcement and the concrete in the range of the crack spacing.

According to the relevant reference[6], $\alpha_{\mathrm{c}}=1-\varepsilon_{c m} / \varepsilon_{s m}, \alpha_{\mathrm{c}}$ is considering the influence of the elongation of the concrete on the crack width, $\alpha_{\mathrm{c}}=0.85$. The calculation formula is shown below:

$$
W=0.85 \varepsilon_{s m} 1_{c r}
$$

Based on the formula of crack width formula (6), the finite element formula of crack width proposed in this paper is shown below:

$$
W=0.85 \sum_{i=1}^{n} \varepsilon_{s i} l
$$

Where, $n$ is the number of steel units within the crack spacing range; $\varepsilon_{s i}$ is the strain value of each steel element in the range of crack spacing; $\sum_{i=1}^{n} 1=1_{c r}$, and the crack spacing is based on the finite element analysis.

\section{Model analysis}

Calculation model and material parameters. In this paper, a finite element analysis model was established for a cross section of the middle section of penstock laid on downstream face of dam of the Three Gorges Hydropower Station. The outer radius of the pipeline is $4.1 \mathrm{~m}$, the inner radius is $3.1 \mathrm{~m}$, the inner steel lining adopts $16 \mathrm{MnR}$ steel, the thickness is $16 \mathrm{~mm}$, the outer layer of the ring is $3 \phi 36$, the middle layer is $3 \phi 32$, the inner layer is $3 \phi 28$, the pipeline and the dam side groove connection part are set with $15 \mathrm{mmPS}$ foam plastic pad floor. The pipeline section and the model grid are shown in Fig2.
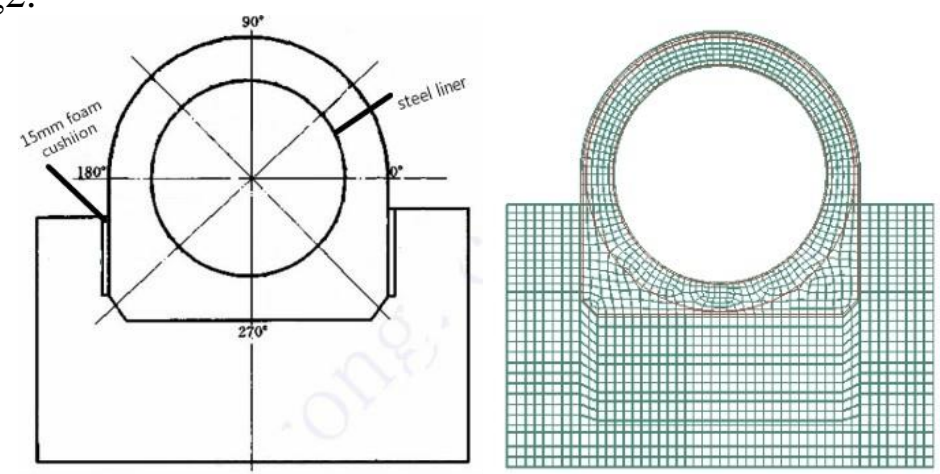

Fig.2 Penstock section and grid

The steel liner adopts the planar four-node plate shell element, the steel bar adopts the two-point bar unit, the concrete is the eight-node hexahedral element. Finite element analysis model is divided into 2189 units, of which 384 steel units, steel lining unit 104, concrete unit 1701. The origin of the coordinate is in the lower left corner of the dam, the horizontal axis perpendicular to the tube axis is the $\mathrm{X}$-axis, the vertical axis is the $\mathrm{Y}$-axis. Dam concrete strength grade $\mathrm{C} 15$, concrete outsourcing ordinary C25 concrete, the material parameters shown in table 1. The calculated load mainly includes the design of the internal pressure consistent with the model test $1.21 \mathrm{MPa}$ and the structure of the weight. This calculation does not take into account the temperature load and the initial gap between the lining and the concrete. The calculated boundary condition is to impose a horizontal constraint on the left and right borders and apply a longitudinal constraint at the bottom. 
Table1. Material mechanical parameters

\begin{tabular}{cccccc}
\hline $\begin{array}{c}\text { Material } \\
\text { name }\end{array}$ & $\begin{array}{c}\text { Density } \\
\left(\mathrm{kN} / \mathrm{m}^{3}\right)\end{array}$ & $\begin{array}{c}\text { Elasticity modulus } \\
(\mathrm{GPa})\end{array}$ & $\begin{array}{c}\text { Poisson' } \\
\text { ratio }\end{array}$ & $\begin{array}{c}\text { Designed tensile } \\
\text { strength (MPa) }\end{array}$ & $\begin{array}{c}\text { Designed compressive } \\
\text { strength (MPa) }\end{array}$ \\
\hline $\mathrm{C} 25$ & 25.0 & 28.0 & 0.167 & 1.78 & 16.7 \\
$\mathrm{C} 15$ & 24.0 & 22.0 & 0.167 & 1.27 & 10.0 \\
$16 \mathrm{Mn}$ & 78.0 & 198.0 & 0.3 & 350 & 350 \\
reinforced & 78.0 & 205.0 & 0.3 & 375 & 375 \\
$\begin{array}{c}\text { Cushion } \\
\text { material }\end{array}$ & 2.0 & 0.001 & 0.3 & 9.4 & - \\
\hline
\end{tabular}

The plastic damage model used in this paper is measured by the relevant reinforced concrete tensile test[7], as shown in Fig.3 and Fig.4.The plastic strain model introduces the plastic strain and the damage correlation, and does not need to presume the position of the crack in advance, and does not simultaneously have large area cracking, which has been widely used in nonlinear numerical analysis of concrete structure.

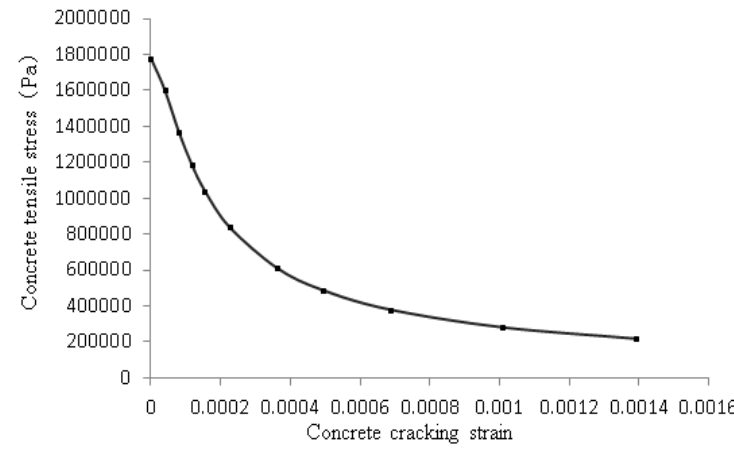

Fig. 3 Concrete tensile softening curve

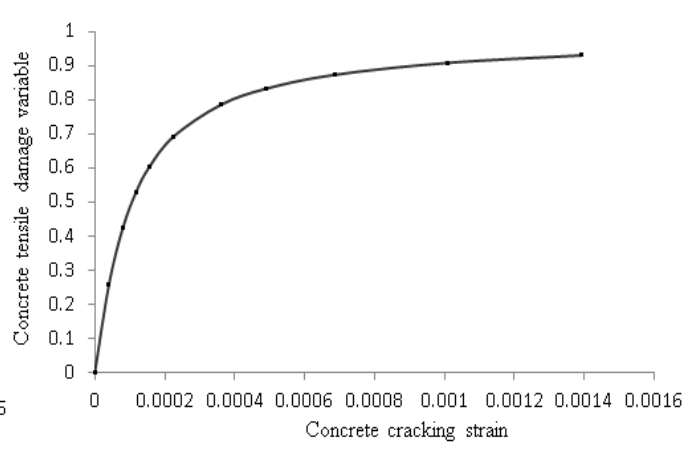

Fig.4 Concrete tensile damage curve

Nonlinear finite element analysis. Damage analysis results show that in the process of concrete damage cracking and expansion, outer concrete of penstock with the increase of water pressure, the concrete around the pipeline head and the middle and left sides of the pipeline waist first appear damage with the increase of the water pressure. When the water pressure increases to $0.686 \mathrm{MPa}$, the damage value of concrete at the left and right sides of the tube reaches the cracking degree of $0.5[8]$, and expand quickly. Basically to the level that one crack is penetrated. The crack propagation path extends from the outer side of the pipeline waist to the inside. Along with the gradual increase of the inside water pressure, the concrete on the inside of the top of the pipeline also cracks, and the expansion path extends from the inside to the outside. In the process of the increasing inside water pressure, cracks continue to come into being and develop. When the water pressure increases to the design value $1.21 \mathrm{MPa}$, there are 21 cracks on the pipeline eventually. The crack distribution is dense on the top and sparse on the lower part. Basically bilateral symmetrical distribution. The damage cracking process showed in Fig.5. 


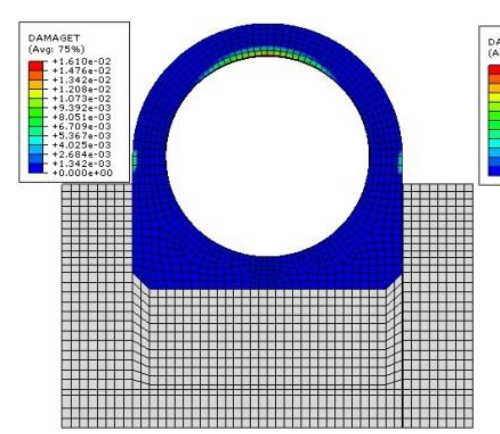

$0.6 \mathrm{MPa}$

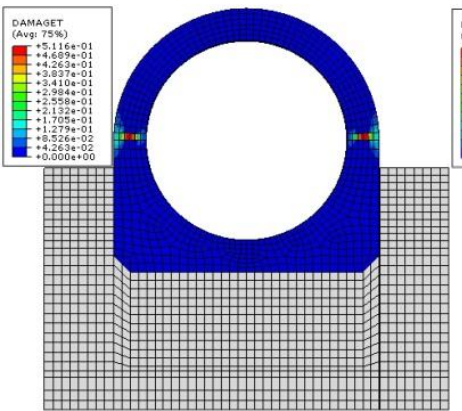

$0.686 \mathrm{MPa}$

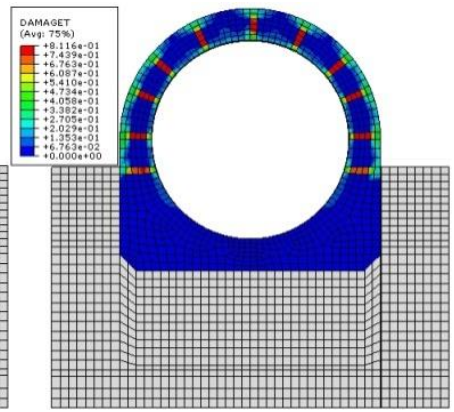

$0.8 \mathrm{MPa}$

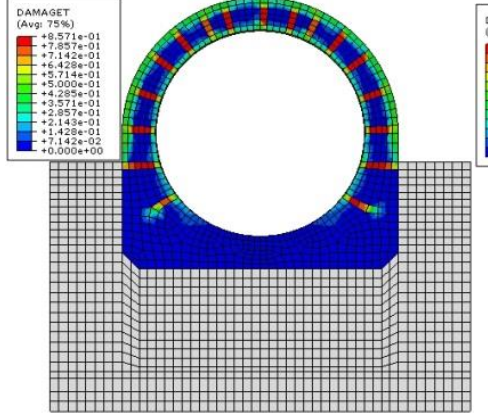

$1.0 \mathrm{MPa}$

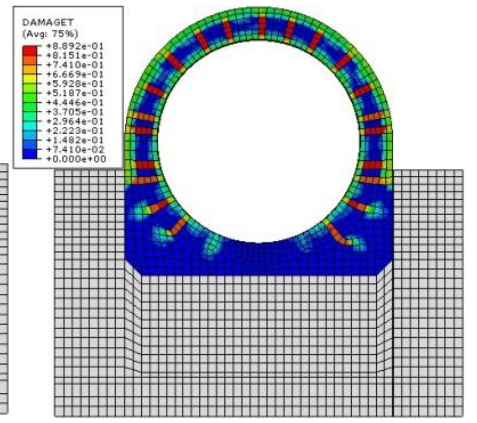

$1.21 \mathrm{MPa}$

Fig.5 Damage cracking process of penstock concrete

In addition, relevant model test research results show that before the cracking of outer concrete of pipeline, inside water pressure is carried by steel liner and surrounding reinforced concrete together. When the water pressure increases to $0.7 \mathrm{MPa}$, the crack appears in the left side of the pipeline waist first, and expand quickly, and to the level of one crack is penetrated. In the process of the increasing inside water pressure from $0.7 \mathrm{MPa}$ to $1.21 \mathrm{MPa}$, there are many tiny cracks generate on the upper half of the pipeline gradually. And generate 20penetration cracks, and its distribution is approximately bilateral symmetrical. Most of cracks are on the upper half of the pipeline, showed in Fig.6[9]. From this we can see that the above numerical results show that the initial crack load and the damage cracking rule of concrete are close to the model test.

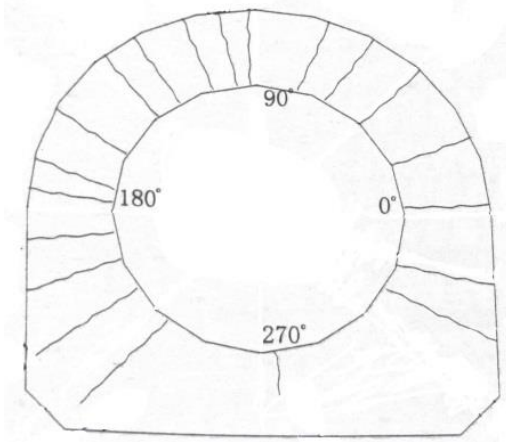

Fig.6 Penstock model test cracking profile

Under the influence of design water pressure, there will be a wide range of damage crack in the outer concrete of pipeline. The water pressure will be mainly carried by steel liner and steel bar. In this paper, the liner and ring to steel in the bar stress in typical feature points $\left(0^{\circ} 、 45^{\circ} 、 90^{\circ} 、 135^{\circ}\right.$ 、 $\left.180^{\circ} 、 225^{\circ} 、 270^{\circ} 、 315^{\circ}\right)$ of comparison between numerical analysis and model test are showed in table 2. 
Table2 Steel stresses on typical section (unit: MPa)

\begin{tabular}{|c|c|c|c|c|c|c|c|c|c|c|c|c|}
\hline \multirow{2}{*}{$\begin{array}{l}\text { Featur } \\
\text { e site }\end{array}$} & \multicolumn{3}{|c|}{ Steel lining } & \multicolumn{3}{|c|}{ Inner reinforced } & \multicolumn{3}{|c|}{ Middle reinforced } & \multicolumn{3}{|c|}{ Outer reinforced } \\
\hline & $\begin{array}{l}\text { Numerica } \\
1 \text { value }\end{array}$ & $\begin{array}{c}\text { Test } \\
\text { value }\end{array}$ & $\begin{array}{l}\text { Deviatio } \\
\mathrm{n} \text { value }\end{array}$ & $\begin{array}{c}\text { Numeric } \\
\text { al value }\end{array}$ & $\begin{array}{c}\text { Test } \\
\text { valu } \\
\text { e } \\
\end{array}$ & $\begin{array}{l}\text { Deviatio } \\
\mathrm{n} \text { value }\end{array}$ & $\begin{array}{l}\text { Numeric } \\
\text { al value }\end{array}$ & $\begin{array}{c}\text { Test } \\
\text { valu } \\
\text { e }\end{array}$ & $\begin{array}{c}\text { Deviatio } \\
\mathrm{n} \text { value }\end{array}$ & $\begin{array}{l}\text { Numeric } \\
\text { al value }\end{array}$ & $\begin{array}{c}\text { Test } \\
\text { valu } \\
\text { e } \\
\end{array}$ & $\begin{array}{l}\text { Deviation } \\
\text { value }\end{array}$ \\
\hline $0^{\circ}$ & 75.6 & 79.3 & -3.7 & 109.9 & 108 & 1.9 & 169.6 & 174 & -4.4 & 124.5 & $\begin{array}{c}134 . \\
9\end{array}$ & -10.4 \\
\hline $45^{\circ}$ & 93.9 & 84 & 9.9 & 82.3 & 52.9 & 29.4 & 93.3 & 95.5 & -2.2 & 56.9 & 68.7 & -11.8 \\
\hline $90^{\circ}$ & 120.4 & $\begin{array}{c}125 . \\
2\end{array}$ & -4.8 & 170.7 & $\begin{array}{c}152 . \\
9\end{array}$ & 17.8 & 132.5 & $\begin{array}{c}119 . \\
1\end{array}$ & 13.4 & 88.5 & 85.1 & 3.4 \\
\hline $135^{\circ}$ & 90.6 & 84 & 6.6 & 168.5 & $\begin{array}{c}140 . \\
7\end{array}$ & 27.8 & 91.7 & 94.5 & -2.8 & 94.3 & $\begin{array}{c}101 . \\
5\end{array}$ & -7.2 \\
\hline $180^{\circ}$ & 89.7 & 86.2 & 3.5 & 64.3 & 43.3 & 21 & 77.8 & 80 & -2.2 & 93.4 & 87.7 & 5.7 \\
\hline $225^{\circ}$ & 62.9 & 57 & 5.9 & 53.5 & 38.3 & 15.2 & 15.2 & 26.2 & -11 & 2.8 & 4.1 & -1.3 \\
\hline $270^{\circ}$ & 19.8 & 22 & -2.2 & 20.3 & 10.3 & 10 & 12 & 17.6 & -5.6 & 11.3 & 9.8 & 1.5 \\
\hline $315^{\circ}$ & 36.8 & 33.6 & 3.2 & 42.3 & 31.6 & 10.7 & 15.1 & 11.5 & 3.6 & 3.4 & 1.2 & 2.2 \\
\hline
\end{tabular}

In the table 2, we can see that under the influence of design water pressure, the law of stress distribution of steel liner and steel is nearly consistent by finite element calculation and model test. In the finite element calculation, the maximum stress of steel liner appears on the top of pipeline, the maximum stress is $120.4 \mathrm{MPa}$. The maximum stress of steel appears on the inside steel at top of pipeline, maximum stress is $170.4 \mathrm{MPa}$. Stress of inside steel is greater than outside at top of pipeline, which is opposite at pipeline waist. Due to the dam body concrete acts on the bottom of the pipeline, the outer concrete of the pipeline which is close to the dam body has less damage, so the stress of the reinforcement is generally smaller at the bottom.

A study is made of the displacement of the inner and outer walls of the penstock behind the dam under the influence of water pressure at various levels, and make the comparison between the numerical analysis value and the model test list, showed in table 3. The displacement of pipeline under the influence of water pressure at various levels is showed in Fig.7.
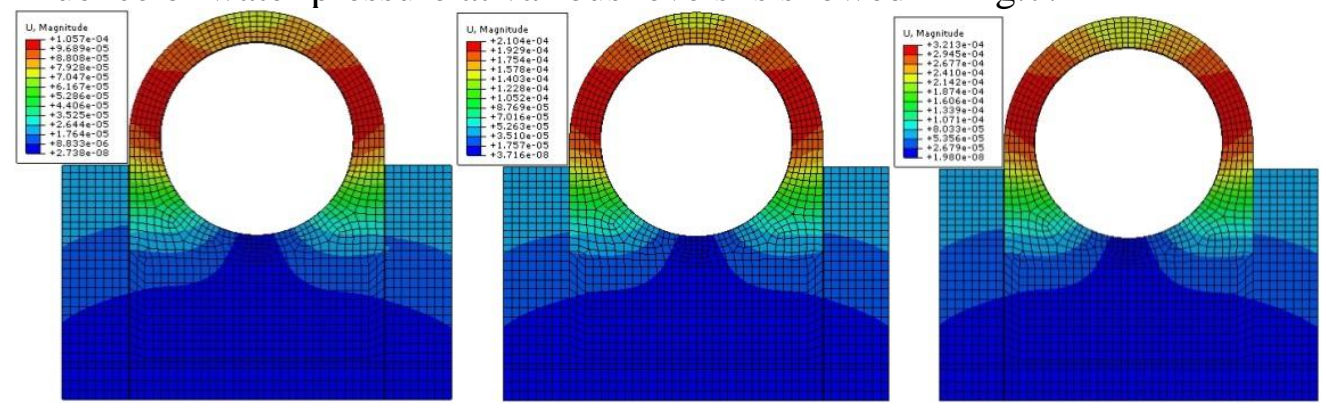

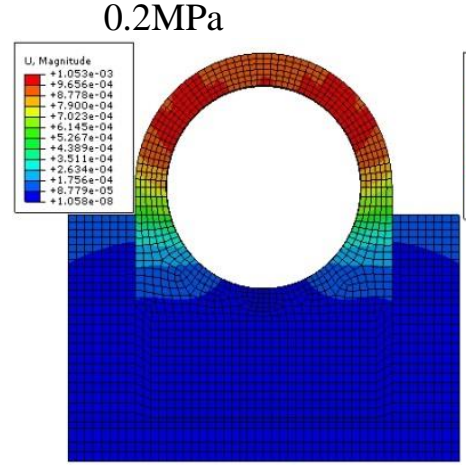

$0.8 \mathrm{MPa}$
$0.4 \mathrm{MPa}$

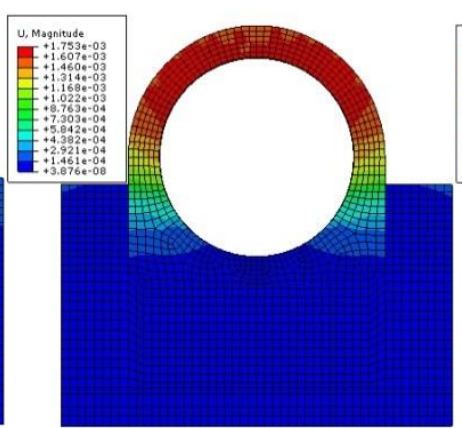

$1.0 \mathrm{MPa}$
$0.6 \mathrm{MPa}$

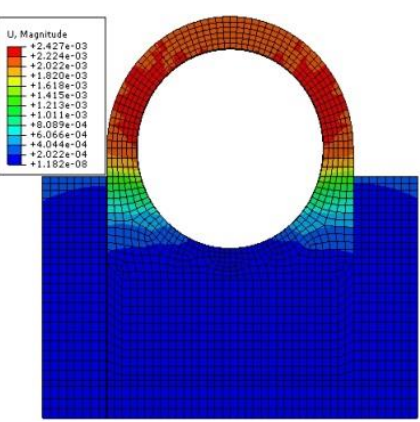

$1.21 \mathrm{MPa}$

Fig.7 Damage of back pipeline with internal water pressure

From the Fig.6,we can see that when inside water pressure is less than $0.6 \mathrm{MPa}$, which means outer concrete has no crack. The displacement of pipeline is small, larger displacement parts are grouped at pipeline waist of $45^{\circ}$ and $135^{\circ}$. When the water pressure increases to $0.8 \mathrm{MPa}$, concrete of pipeline cracking occurs, and displacement of pipeline increases obviously. As the increases of 
inside water pressure, the displacement of upper half of the pipeline has trend of sudden increase. The displacement of lower half of pipeline is small, and there is almost no displacement at the bottom of pipeline.

Table3 Comparison and analysis of penstock displacement

\begin{tabular}{|c|c|c|c|c|c|c|c|c|c|c|c|}
\hline & \multicolumn{2}{|c|}{$0^{\circ}$} & \multicolumn{2}{|c|}{$45^{\circ}$} & \multicolumn{2}{|c|}{$90^{\circ}$} & \multicolumn{2}{|c|}{$135^{\circ}$} & \multicolumn{2}{|c|}{$180^{\circ}$} \\
\hline & & $\begin{array}{c}\text { Inner } \\
\text { wall }\end{array}$ & $\begin{array}{c}\text { Outer } \\
\text { wall }\end{array}$ & $\begin{array}{c}\text { Inner } \\
\text { wall }\end{array}$ & $\begin{array}{c}\text { Outer } \\
\text { wall }\end{array}$ & $\begin{array}{c}\text { Inner } \\
\text { wall }\end{array}$ & $\begin{array}{c}\text { Outer } \\
\text { wall }\end{array}$ & $\begin{array}{c}\text { Inner } \\
\text { wall } \\
\end{array}$ & $\begin{array}{c}\begin{array}{c}\text { Outer } \\
\text { wall }\end{array} \\
\end{array}$ & $\begin{array}{c}\text { Inner } \\
\text { wall }\end{array}$ & $\begin{array}{l}\text { Outer } \\
\text { wall }\end{array}$ \\
\hline \multirow{3}{*}{$0.2 \mathrm{MPa}$} & $\begin{array}{c}\text { Numerical value } \\
(\mathrm{mm})\end{array}$ & 0.08 & 0.08 & 0.10 & 0.09 & 0.08 & 0.07 & 0.10 & 0.09 & 0.09 & 0.08 \\
\hline & Test value $(\mathrm{mm})$ & 0.04 & 0.01 & 0.06 & 0.01 & 0.06 & 0.03 & 0.04 & 0.02 & 0.05 & 0.04 \\
\hline & $\begin{array}{c}\text { Deviation value } \\
(\mathrm{mm})\end{array}$ & 0.04 & 0.07 & 0.04 & 0.08 & 0.02 & 0.04 & 0.06 & 0.07 & 0.04 & 0.04 \\
\hline \multirow{3}{*}{$0.4 \mathrm{MPa}$} & $\begin{array}{c}\text { Numerical value } \\
(\mathrm{mm})\end{array}$ & 0.17 & 0.16 & 0.19 & 0.19 & 0.16 & 0.15 & 0.19 & 0.18 & 0.17 & 0.16 \\
\hline & Test value $(\mathrm{mm})$ & 0.11 & 0.06 & 0.15 & 0.08 & 0.16 & 0.11 & 0.13 & 0.09 & 0.13 & 0.10 \\
\hline & $\begin{array}{l}\text { Deviation value } \\
(\mathrm{mm})\end{array}$ & 0.06 & 0.10 & 0.04 & 0.11 & 0.00 & 0.04 & 0.06 & 0.09 & 0.04 & 0.06 \\
\hline \multirow{3}{*}{$0.6 \mathrm{MPa}$} & $\begin{array}{c}\text { Numerical value } \\
(\mathrm{mm})\end{array}$ & 0.27 & 0.24 & 0.30 & 0.29 & 0.25 & 0.22 & 0.30 & 0.29 & 0.27 & 0.24 \\
\hline & Test value $(\mathrm{mm})$ & 0.16 & 0.11 & 0.23 & 0.16 & 0.25 & 0.19 & 0.20 & 0.15 & 0.22 & 0.17 \\
\hline & $\begin{array}{l}\text { Deviation value } \\
(\mathrm{mm})\end{array}$ & 0.11 & 0.13 & 0.07 & 0.13 & 0.00 & 0.03 & 0.10 & 0.14 & 0.05 & 0.07 \\
\hline \multirow{3}{*}{$0.8 \mathrm{MPa}$} & $\begin{array}{c}\text { Numerical value } \\
(\mathrm{mm})\end{array}$ & 0.65 & 0.60 & 1.00 & 0.94 & 1.00 & 0.88 & 1.00 & 0.94 & 0.66 & 0.61 \\
\hline & Test value $(\mathrm{mm})$ & 0.24 & 0.20 & 0.57 & 0.53 & 0.69 & 0.63 & 0.61 & 0.53 & 0.53 & 0.42 \\
\hline & $\begin{array}{l}\text { Deviation value } \\
(\mathrm{mm})\end{array}$ & 0.41 & 0.40 & 0.43 & 0.41 & 0.31 & 0.25 & 0.39 & 0.41 & 0.13 & 0.19 \\
\hline \multirow{3}{*}{$1.0 \mathrm{MPa}$} & $\begin{array}{c}\text { Numerical value } \\
(\mathrm{mm})\end{array}$ & 1.16 & 1.07 & 1.66 & 1.65 & 1.67 & 1.53 & 1.65 & 1.64 & 1.15 & 1.06 \\
\hline & Test value $(\mathrm{mm})$ & 0.45 & 0.43 & 1.19 & 1.15 & 1.16 & 1.18 & 1.02 & 0.94 & 0.73 & 0.70 \\
\hline & $\begin{array}{l}\text { Deviation value } \\
\quad(\mathrm{mm})\end{array}$ & 0.71 & 0.64 & 0.47 & 0.50 & 0.51 & 0.35 & 0.63 & 0.70 & 0.42 & 0.36 \\
\hline \multirow{3}{*}{$1.21 \mathrm{MPa}$} & $\begin{array}{l}\text { Numerical value } \\
(\mathrm{mm})\end{array}$ & 1.96 & 1.75 & 2.26 & 2.25 & 2.20 & 2.03 & 2.25 & 2.25 & 1.96 & 1.75 \\
\hline & Test value $(\mathrm{mm})$ & 1.66 & 1.68 & 1.75 & 1.72 & 1.77 & 1.71 & 1.72 & 1.66 & 1.28 & 1.23 \\
\hline & $\begin{array}{l}\text { Deviation value } \\
(\mathrm{mm})\end{array}$ & 0.30 & 0.07 & 0.51 & 0.53 & 0.43 & 0.32 & 0.53 & 0.59 & 0.68 & 0.52 \\
\hline
\end{tabular}

From the data analysis above, we can see that under the influence of water pressure at various levels, the displacement of $45^{\circ}$ section to $135^{\circ}$ is larger, and the displacement values obtained by numerical analysis of each section are generally larger than the measured values of model tests. After cracking of pipeline, due to tensile deformation, the displacement of the inner wall of pipeline is basically larger than that of pipeline outer wall. On the whole, there is little deviation between the numerical analysis of pipeline displacement and the measured value of the model, and trend of displacement is basically the same.

Crack width analysis. As the water pressure increases, the crack development process of pipeline concrete is shown in Fig.8. The number of cracks increased from 2 in the initial crack to 21 under the designed internal pressure, the 21 cracks formed under the influence of the design water pressure are numbered clockwise. Numerical analysis results show that the average crack spacing is 0.93 meters. But In the model test under the design of water pressure, 20 radial through cracks are finally formed, the average distance between crack is about 0.9-1.0 meters. In this paper, the calculated values of the finite element method and the calculated values of the crack width are analyzed and compared with the calculated values of the concrete under the design of internal water pressure. The calculated values of the crack width finite element method are calculated using the formula (7)described in this paper. The crack spacing is calculated by numerical analysis.

The specifications formula for calculating the crack width as follows[10]:

$$
\begin{aligned}
& W_{\max }=\alpha_{c r} \varphi \frac{\sigma_{s}}{E_{S}}\left(1.9 C_{S}+0.08 \frac{d_{e q}}{\rho_{t e}}\right) \\
& \varphi=1.1-0.65 \frac{f_{t k}}{\rho_{t e} \sigma_{s}}
\end{aligned}
$$




$$
\alpha_{c r}=\tau_{1} \tau_{s} \beta \alpha_{c}
$$

Where, $\tau_{l}$ is the long-term effect of load; $\tau_{s}$ is the short-term crack width expansion factor; $\alpha_{c}$ is the influence coefficient of concrete elongation on crack width in cracks; $\beta$ is the crack spacing expansion factor, the meaning of the rest of the reference material is explained in the specification[10].

According to the relevant research in reference[11]. Due to the randomness and discreteness of the crack width, in actual engineering, the maximum crack width is equal to the calculated value of the average crack width, multiplied by the short crack width expansion factor. In addition, because of the bond slip, creep and stress relaxation of the concrete tensile zone, the average strain of the tensile steel will continue to increase. At the same time, the shrinkage of concrete will also increase the width of concrete cracks. So consider the influence of long-term load, the maximum crack width has to be multiplied by the coefficient of expansion under the long-term load. However, due to the short test cycle in the laboratory, so this paper only consider the short-term expansion of the crack width effect, while the long-term load under the crack width expansion factor is not considered.

The calculation value of the crack width specification formula and the calculation value of the finite element method are shown in table 4 and table 5.

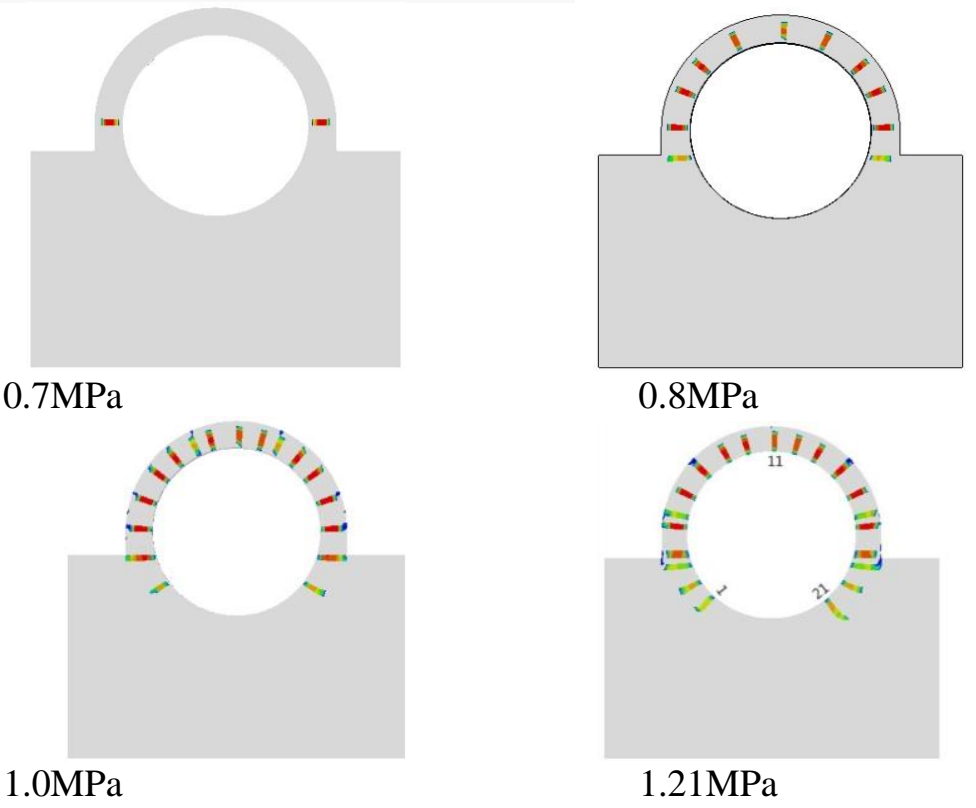

Fig.8 The process of penstock concrete cracking

Table4 Calculation of crack width specification formula

\begin{tabular}{ccc}
\hline $\begin{array}{c}\text { Crack } \\
\text { number }\end{array}$ & $\begin{array}{c}\text { Inner crack } \\
\text { width }(\mathrm{mm})\end{array}$ & $\begin{array}{c}\text { Lateral crack } \\
\text { width }(\mathrm{mm})\end{array}$ \\
\hline 1 & 0.091 & 0.002 \\
2 & 0.117 & 0.003 \\
3 & 0.066 & 0.099 \\
4 & 0.204 & 0.075 \\
5 & 0.260 & 0.126 \\
6 & 0.065 & 0.182 \\
7 & 0.270 & 0.078 \\
8 & 0.278 & 0.059 \\
9 & 0.250 & 0.063 \\
10 & 0.246 & 0.063 \\
11 & 0.285 & 0.055 \\
12 & 0.234 & 0.063 \\
13 & 0.250 & 0.064 \\
14 & 0.275 & 0.059 \\
15 & 0.268 & 0.079 \\
16 & 0.065 & 0.182 \\
17 & 0.256 & 0.127 \\
18 & 0.203 & 0.076 \\
19 & 0.065 & 0.099 \\
20 & 0.124 & 0.003 \\
21 & 0.068 & 0.002 \\
\hline
\end{tabular}




\begin{tabular}{|c|c|c|c|}
\hline $\begin{array}{c}\text { Crack } \\
\text { number }\end{array}$ & $\begin{array}{r}\text { Inner crack } \\
\text { width }(\mathrm{mm})\end{array}$ & $\begin{array}{l}\text { Middle crack } \\
\text { width }(\mathrm{mm})\end{array}$ & $\begin{array}{l}\text { Lateral crack } \\
\text { width }(\mathrm{mm})\end{array}$ \\
\hline 1 & 0.107 & 0.054 & 0.000 \\
\hline 2 & 0.240 & 0.228 & 0.000 \\
\hline 3 & 0.264 & 0.217 & 0.120 \\
\hline 4 & 0.220 & 0.197 & 0.162 \\
\hline 5 & 0.252 & 0.230 & 0.227 \\
\hline 6 & 0.130 & 0.167 & 0.174 \\
\hline 7 & 0.237 & 0.306 & 0.276 \\
\hline 8 & 0.266 & 0.302 & 0.288 \\
\hline 9 & 0.412 & 0.437 & 0.408 \\
\hline 10 & 0.416 & 0.401 & 0.393 \\
\hline 11 & 0.280 & 0.208 & 0.262 \\
\hline 12 & 0.426 & 0.380 & 0.367 \\
\hline 13 & 0.371 & 0.331 & 0.333 \\
\hline 14 & 0.279 & 0.252 & 0.262 \\
\hline 15 & 0.416 & 0.402 & 0.386 \\
\hline 16 & 0.411 & 0.437 & 0.406 \\
\hline 17 & 0.373 & 0.477 & 0.443 \\
\hline 18 & 0.359 & 0.375 & 0.357 \\
\hline 19 & 0.141 & 0.186 & 0.154 \\
\hline 20 & 0.313 & 0.225 & 0.000 \\
\hline 21 & 0.264 & 0.180 & 0.000 \\
\hline
\end{tabular}

From the data in table 4 and table 5, it can be seen that under the design of internal water pressure, the calculation formula of the inner crack width of concrete in the concrete pipeline is basically larger than the width of the outer crack, the width of the crack width is less than $0.20 \mathrm{~mm}$. The maximum width is $0.285 \mathrm{~mm}$, located at the top of the pipeline. The fractal width finite element method shows that the width of the outer crack is smaller than the width of the inner and middle cracks in the same crack. The fractal width finite element method shows that the width of the outer crack is smaller than the width of the inner and middle cracks in the same crack, and the maximum width of the inner crack is $0.426 \mathrm{~mm}$, which is located at the top of the pipeline and the maximum of the middle crack width is $0.477 \mathrm{~mm}$, located in the right side of the pipeline waist position, the maximum width of the lateral crack $0.443 \mathrm{~mm}$, also located in the right side of the pipeline waist position. The results of the model test show that[9]: under the action of the design of internal water pressure, the pipeline at the waist of the largest crack width, the middle of the pipeline wall width of more than $0.3 \mathrm{~mm}$.In the actual project, the measured maximum crack width is often greater than the design limit of $0.3 \mathrm{~mm}$, or even limit the value of 2-7 times. Obviously, the results obtained by the finite element method of crack width proposed in this paper are closer to the measured crack width values of many hydropower station pressure pipelines.

\section{Conclusions}

As the research object in this paper, the Three Gorges Hydropower station penstock, axial tensile test and plastic damage model based on the concrete crack width calculation method proposed in this paper. The problems such as the initial crack load, the crack propagation law, the deformation characteristics, the steel stress distribution law and the concrete crack width are studied, and the results are compared with the corresponding model test results. The finite element calculation results are basically consistent with the model test. From the point of view of the emergence and expansion of the concrete crack in the pipeline, the concrete crack first appears on the outside of the pipeline waist, and the subsequent cracks gradually appear inside the tube roof and the left and right 
$45^{\circ}$ position, and the initial crack load is about $0.7 \mathrm{MPa}$;Steel stress distribution is consistent, the upper half of the steel pipe stress is greater than the lower half of the steel stress, the maximum deviation of $29.4 \mathrm{MPa}$; The numerical analysis of the pipeline displacement is consistent with the measured value of the model, and the displacement value of the pipe wall is larger than that of the outer wall, and the displacement trend is consistent; The maximum crack width obtained by the finite element method of crack width is $0.477 \mathrm{~mm}$, which is obviously larger than that of the crack width calculated from the standard crack width $0.285 \mathrm{~mm}$.For the actual project, although the calculation value of the crack width of the actual project can meet the design requirement of $0.3 \mathrm{~mm}$ less than the allowable crack width limit in the engineering design stage, the crack width observed in the actual project of the pressure pipe of the hydropower station is often larger, the measured width of the crack even reached the design limit of 2-7 times. The results obtained by the finite element method of crack width proposed in this paper are closer to the measured crack width values of many hydropower station pressure pipelines.

\section{Acknowledgements}

This work was financially supported by the National Natural Science Foundation of China(No. 51379107)

\section{References}

[1] Shuohong Jiang,Zhong Xia,Xiaoping Xie: (Science Press, Beijing,2007)

[2]NgoD, ScordelisAC. Finite element analysis of reinforced concrete beams.ACI.Vol 64,No.3,p152-163,1967.

[3] Yupu Song,Guofan Zhao. Finite Element Analysis of Crack Width of Reinforced Concrete Members. Journal of Dalian Institute of Technology. Vol24, No.4, p115-119,1985(In Chinese)

[4] Shengxing Wu. Finite element method of crack width computation in concrete structures. Chinese Journal of Computational Mechanics. Vol14, No.1, p69-77,1997(In Chinese)

[5] Xiaodan Ren,Jie Li. Damage Theory Based Analysis of Crack Opening Width for RC Structures.Journal of Tongji University(Nature Science).Vol43,No.8,p1129-1134,2015 (In Chinese)

[6] Peiling He,Weizhong He:Principle of Concrete Design(China Water Power Press, Beijing,2009).

[7] Hongzhou Ran:Experimental study on tensile properties of reinforced concrete (China Three Gorges University Press, Yichang 2015).

[8] Ming Cao. Research on damage plastic calculation method of ABAQUS concrete damage plasticity Model.Highway Engineering.Vol1,No.2,p51-54,2012(In Chinese)

[9] University of Hydraulic and Electric Engineering. Large scale plane structure model test research on steel lined reinforced concrete penstock in Three Gorges Hydropower station(Hydropower engineering institute of Gezhouba, Yichang 1996).

[10] GB50010-2002,Design code for design concrete structures.Beijing: China Building Industry Publishing House Press, 2002.

[11] Youlin Xu,Shi Zhou. Understanding and Application of Design Code for Concrete Structures(China Building Industry Publishing House, Beijing,2002) 